\title{
Pengaruh Corporate Governance, Ukuran Perusahaan dan Leverage Terhadap Kualitas Laporan Keuangan Dengan Profitabilitas Sebagai Variabel Moderating Perusahaan Manufaktur di BEI Tahun 2014- 2018",
}

\author{
Mulya Rafika \\ Mulya_rafika@yahoo.co.id \\ Dosen Tetap Sekolah Tinggi Ilmu Ekonomi (STIE) Labuhanbatu
}

\begin{abstract}
ABSTRAK
Tujuan penelitian ini adalah (1)Menemukan bukti empiris pengaruh corporate governance, ukuran perusahaan, leverage dan profitabilitas secara parsial dan simultan berpengaruh terhadap kualitas laporan keuangan. (2) Menemukan bukti empiris pengaruh profitabilitas memoderasi hubungan corporate governance, ukuranperusahaandanleverage terhadap kualitas laporan keuangan.Populasi yang akan digunakan dalam penelitian ini adalah semua perusahaan manufaktur yang terdaftar di BEI pada tahun 2014-2018 yang berjumlah 132 perusahaan. Sampel dipilih dengan menggunakan metode purposive sampling berjumlah 65 perusahaan. Data diolah menggunakan metode uji statistik regresi linier berganda untuk hipotesis pertamadan uji moderating menggunakan uji residual untuk hipotesis kedua dengan menggunakan software SPSS. Hasil penelitian ini membuktikan pada hipotesis pertama bahwa variabel Kepemilikan Institusional (KI), Ukuran Perusahaan (SIZE), Leverage (DER) dan Profitabilitas (ROA) secara simultan berpengaruh signifikan terhadapKualitas Laporan Keuangan (kualitas laporan keuangan) pada perusahaan manufaktur yang terdaftar di Bursa Efek Indonesia untukperiode2014-2018. Kepemilikan Institusional (KI), Ukuran Perusahaan (SIZE) dan Leverage (DER)berpengaruh signifikan terhadap Kualitas Laporan Keuangan, sedangkan Profitabilitas (ROA) berpengaruh tidak signifikan pada perusahaa nmanufaktur terdaftar di Bursa Efek Indonesia untuk periode2014-2018. Variabelprofitabilitasbelum dapat dikatakan sebagaiVariabel moderating memperkuatataumemperlemah dan memoderasi hubungan KI, SIZE,dan DER terhadap Kualitas Laporan Keuangan padaperusahaan manufaktur yang terdaftar di BEI untuk periode2014-2018.
\end{abstract}

Kata kunci :Kepemilikan Institusional (KI), Ukuran Perusahaan (SIZE), Leverage (DER) dan Profitabilitas (ROA). 


\section{PENDAHULUAN}

Salah satu usaha untuk mengembangkan suatu perusahaan dan menarik investor kedalamnya adalah melalui pemberian informasi akuntansi yang akurat. Informasi akuntansi yang berhubungan dengan kinerja perusahaan merupakan kebutuhan yang paling mendasar pada proses pengambilan keputusan bagi investor di pasar modal. Salah satu sumber informasi tersebut adalah laporan keuangan. Laporan keuangan merupakan salah satu sarana untuk menunjukkan kinerja manajemen yang diperlukan investor dalam menilai maupun memprediksi kapasitas perusahaan menghasilkan arus kas dari sumber daya yang ada (Ikatan Akuntan Indonesia, 2004). Laporan keuangan juga merupakan suatu bentuk pertanggungjawaban manajemen atas pengelolaan sumber-sumber daya ekonomi yang telah dipercayakan kepadanya (Lako, 2007).

Adanya agency conflict mengakibatkan timbulnya asimetri informasi antara pemegang saham dan manajer perusahaan. Asimetri informasi ini juga merupakan faktor yang mempengaruhi investasi perusahaan karena akan membuat keputusan investasi tersebut menjadi kurang berkualitas. Keberadaan dari asimetri informasi ini menyebabkan tidak tercapainya tujuan awal dari investasi perusahaan, yaitu peningkatan kesejahteraan pemegang saham. Asimetri informasi tersebut akan mengakibatkan perbedaan informasi yang diperoleh diantara kedua pihak. Hal tersebut bisa mengakibatkan perusahaan mengalami overivestment atau underinvestment (Bushman et al., 2006). Untuk bisa mencegah timbulnya asimetri informasi yang dapat menyebabkan over- atau underinvestment dibutuhkan sebuah fungsi monitoring yang cukup kuat dari pemegang saham. Fungsi monitoring bagi pemegang saham dapat ditingkatkan melalui laporan keuangan perusahaan yang berkualitas (Beatty et al., 2009)

Laporan keuangan yang berkualitas menyajikan segala informasi mengenai bisnis perusahaan secara relevant dan reliable. Untuk itu dibutuhkan pula tingkat pengungkapan yang baik dari perusahaan itu sendiri (Bens and Monahan, 2002). Verdi (2006) menemukan bahwa laporan keuangan memiliki hubungan negatif terhadap over- atau underinvestment, dimana kualitas yang baik dari sebuah laporan keuangan dapat meningkatkan efisiensi investasi perusahaan dengan cara mengurangi asimetri informasi. Kemudian Biddle et al. (2009) menemukan bahwa kualitas laporan keuangan memiliki hubungan negatif dengan kondisi over- dan underinvestment. Adanya kualitas pelaporan keuangan yang baik akan dapatmeningkatkan fungsi monitoring dari pemegang saham sehingga dapat mengurangi kemungkinan terjadinya kondisi over- atau underinvestment. Chen et al. (2010) juga melakukan p 1 an yang sama namun pada sampel perusahaan-perusahaan tertutup (private ) di Amerika. Hasil yang ditemukan bahwa kualitas laporan keuangan berhubungan negatif dengan kondisi over- dan underinvestment, walaupun pada perusahaan tertutup. 
Informasi adalah sekumpulan keterangan yang bermanfaat bagi para pengambil keputusan dalam menjalankan organisasi. Informasi menghasikan data dalam bentuk yang lebih bermanfaat bagi penerima informasi yang mencerminkan peristiwa-peristiwa nyata yang digunakan untuk mengambil keputusan. Informasi keuangan memuat data-data keuangan yang tersaji secara deskripsi tentang kondisi keuangan perusahaan, informasi keuangan termuat dalam laporan keuangan. Di pasar modal, laporan keuangan perusahaan memiliki fungsi yang sangat strategis. Laporan keuangan merupakan informasi yang menggambarkan dan untuk menilai kinerja perusahaan, terlebih bagi perusahaan yang sahamnya telah tercatat dan diperdagangkan di bursa. Informasi yang terdapat dalam laporan keuangan perusahaan dapat memberikan analisa laporan keuangan untuk menilai kinerja perusahaan yang juga mencerminkan fundamental perusahaan sehingga informasi tersebut dapat memberikan landasan bagi keputusan investasi. Ada bagian dalam laporan keuangan yang sering tidak diperhatikan investor, seperti laporan direksi atau manajemen perusahaan. Padahal, pada bagian tersebut manajemen sering kali menjelaskan mengenai perjalanan perusahaan selama ini, prospek dan recana mereka kedepannya. Dari sini shareholder juga dapat melihat seberapa yakin manajemen terhadap prospek perusahaan. Dari ulasan manajemen ini mereka dapat pula melihat perkembangan bisnis terakhir, produk, persaingan dan kondisi keuangannya.

Angka-angka yang tertera dalam laporan keuangan itu menggambarkan kinerja perusahaan dan kemampuan manajemennya dalam mengelola usaha tersebut. Dari angka tersebut juga dapat dijadikan dasar untuk memproyeksikan apa yang akan terjadi.

Unsur corporate governance terdapat dalam laporan keuangan yang merupakan sebuah rangkaian tentang sebuah proses, kebiasaan, kebijakan, aturan, dan institusi yang mempengaruhi pengarahan, pengelolaan, serta pengontrolan suatu perusahaan atau korporasi. Penerapan corporate governance yang baik terdapat pengawasan dari dewan komisaris sehingga laporan keuangan yang dihberdampak pada laporan keuangan yang dihasilkan, perusahaan atau manajemen akan sulit untuk melakukan manipulasi akuntansi karena asilkan sesuai dengan keadaaan yang sebenarnya dan berintegritas (Nuryanah, 2005). Corporate governance dalam penelitian ini diproksi dengan kepemilikan institusional.

Selain keberadaan corporate governance dalam perusahaan, ukuran perusahaan juga dapat mempengaruhi integritas informasi laporan keuangan. Brigham dan Houston (2001) menyatakan ukuran perusahaan merupakan rata-rata total aset bersih untuk tahun yang bersangkutan sampai beberapa tahun berikutnya. Perusahaan dengan ukuran besar diasumsikan dengan jumlah aktiva dan tingkat pendapatan yang besar sehingga menghasilkan laba yang tinggi. 
Sebaliknya jika penjualan lebih kecil daripada biaya variabel dan biaya tetap maka perusahaan akan menderita kerugian. Francis (1986), menyebutkan perusahaan berskala kecil dibandingkan dengan perusahaan yang berskala besar cenderung kurang menguntungkan. Faktor-faktor pendukung yang dimiliki perusahaan kecil untuk memproduksi barang berjumlah terbatas. Penelitian Diah Kusuma Wardani (2008) menemukan bahwa perusahaan besar dapat memiliki masalah keagenan yang lebih besar (karena lebih sulit untuk dimonitor) sehingga membutuhkan corporate governance yang lebih baik. Di sisi lain, perusahaan kecil bisa memiliki kesempatan tumbuh yang tinggi, sehingga membutuhkan dana eksternal, dan membutuhkan mekanisme corporate governance yang baik.

Dalam menjalankan perusahaan, terkadang perusahaan menggunakan pinjaman dari pihak lain yang dalam istilahnya disebut hutang. Keberadaan hutang dalam menjalankan perusahaan diukur dengan rasio keuangan, yaitu leverage. Rasio leverage dipergunakan untuk mengukur seberapa besar aktiva yang dimiliki perusahaan berasal dari hutang atau modal, sehingga dengan rasio ini dapat diketahui posisi perusahaan dan kewajibannya. Perusahaan yang memiliki hutang yang relatif tinggi akan menerapkan akuntansi konservatif agar laba yang disajikan relatif rendah.

Perusahaan ditunutut untuk dapat memperoleh profitabilitas yang tinggi. Semakin tinggi profitabilitas akan semakin baik. Profitabilitasmerupakan salah satu indikator penting untuk menilai prospek perusahaan di masa datang dan penting untuk diperhatikan investor untuk melihat sejauh mana investasi yang akan dilakukannya di suatu perusahaan mampu memberikan return yang sesuai dengan tingkat yang disyaratkannya. Jadi semakin tinggi ROA suatu perusahaan akan semakin menarik minat investor untuk berinvestasi di perusahaan tersebut, karena apabila ROA perusahaan tinggi berarti return yang akan diterimanya juga semakin besar menunjukkan kualitas laporan keuangan sangat baik.

Perusahaan manufaktur merupakan sebuah perusahaan yang dalam proses produksinya memanfaatkan mesin, peralatan dan tenaga kerja dalam sebuah rangkaian proses produksi. Perusahan manufaktur di BEI memiliki kewajiban untuk menyampaikan informasi penting perusahaan melalui laporan tahunan berbentuk laporan keuangan kepada pihak-pihak terkait yang memerlukan informasi perusahaan dengan tepat waktu, akurat, dapat dimengerti dan obyektif. Fenomena yang terlihat pada perusahaan manufaktur di BEI adalah adanya beberapa faktor yang dapat mempengaruhi kualitas laporan keuangan. Faktor tersebut diantaranya kepemilikian institusional sebagai pengukuran corporate governance, SIZE sebagai sebagai pengukuran ukuran perusahaan, DAR sebagai pengukuran leverage dan ROA sebagamemperlihatkan perkembangan kepemilikan instisusional mengalami peningkatan dimana pada tahun 2010 sebesar 73,49\% meningkat di tahun 2014 menjadi sebesar 80,71\% menunjukkan 
kontrol pemegang saham sangat besar di perusahaan. Ukuran perusahaan juga mengalami peningkatan dimana pada tahun 2014sebesar 14,20 meningkat di tahun 2014 menjadi sebesar 80,71\% menunjukkan pertumbuhan perusahaan cukup pesat. Leverage perusahaan mengalami penurunan dimana pada tahun 2010 sebesar 0,44 turun di tahun 2018 menjadi sebesar 0,42 menunjukkan perusahaan mengurangi hutang-hutangnya. Profitabilitasperusahaan mengalami penurunan dimana pada tahun 2010 sebesar 10,37 turun di tahun 2018 menjadi sebesar 7,86 menunjukkan perusahaan penurunan pencapaian laba bersihnya. Fenomena ini menunjukkan bahwa perlu adanya pengukuran kualitas laporan keuangan yang dipengaruhi oleh variabel-variabel tersebut sehingga dapat menjelaskan aspek penting dalam penilaian kualitas laporan keuangan perusahaan yang lebih baik lagi.

\section{Tujuan Penelitian}

Sesuai dengan rumusan masalah, maka tujuan penelitian ini adalah :

1. Menemukan bukti empiris pengaruh corporate governance, ukuran perusahaan,leverage dan profitabilitas secara parsial dan simultan berpengaruh terhadap kualitas laporan keuangan.

2. Menemukan bukti empiris pengaruh profitabilitas memoderasi hubungan corporate governance, ukuran perusahaan danleverage terhadap kualitas laporan keuangan.

\section{Manfaat Teoritis}

Hasil penelitian ini diharapkan dapat dijadikan bahan bacaan bagi peneliti selanjutnya dan meningkatkan perkembangan terhadap teori-teori yang berhubungan dengan penelitian ini.

\section{Manfaat Praktis}

Hasil penelitian ini diharapkan dapat dijadikan sebagai bahan pertimbangan oleh pemegang saham dalam menganalisis dan menetapkan pilihan investasi yang tepat, sehingga dapat mengoptimalkan keuntungan dan meminimalkan risiko atas investasinya.

\section{TINJAUAN PUSTAKA}

\section{Agency Theory}

Penilaian terhadap suatu perusahaan sangatlah penting sebagai dasar pengambilan keputusan investasi. Nilai perusahaan menjadi tolak ukur bagi investor dan kreditur untuk mengevaluasi kebijakan investasinya yang dikelola oleh manajer (agent) yang tentu saja dapat menimbulkan masalah. Masalah agensi timbul karena adanya konflik kepentingan antara shareholder dan manajer, karena tidak bertemunya utilitas yang maksimal antara mereka. Manajer (agent) sebagai 
pengelola perusahaan lebih banyak mengetahui informasi internal dan prospek perusahaan di masa yang akan datang dibandingkan pemilik (prinsipal). Sehingga ada kemungkinan besar agent tidak selalu bertindak demi kepentingan terbaik principal (Jensen dan Meckling, 1976).

Prinsipal didefinisikan sebagai pihak yang memberikan mandat kepada pihak lain yang disebut agen, untuk dapat bertindak atas nama agen tersebut. Menurut Jensen dan Meckling (1976) ada dua macam bentuk hubungan keagenan, yaitu antara manajer dan pemegang saham (shareholders) dan antara manajer dan pemberi pinjaman (bondholders). Selanjutnya Jansen dan Meckling (1976) menyatakan bahwa hubungan keagenan adalah sebuah kontrak antara manajer (agent) dengan investor (prinsipal).

\section{Kualitas Laporan Keuangan}

Informasi adalah sekumpulan keterangan yang bermanfaat bagi para pengambil keputusan dalam menjalankan organisasi. Informasi menghasikan data dalam bentuk yang lebih bermanfaat bagi penerima informasi yang mencerminkan peristiwa-peristiwa nyata yang digunakan untuk mengambil keputusan. Informasi keuangan memuat data-data keuangan yang tersaji secara deskripsi tentang kondisi keuangan perusahaan, informasi keuangan termuat dalam laporan keuangan. Laporan keuangan adalah informasi keuangan suatu perusahaan pada suatu periode akuntansi yang dapat digunakan untuk menggambarkan kinerja suatu perusahaan (Kasmir, 2011). Laporan keuangan yang baik adalah laporan keuangan yang berkualitas.

\section{Corporate Governance}

Unsur corporate governance terdapat dalam laporan keuangan yang merupakan sebuah rangkaian tentang sebuah proses, kebiasaan, kebijakan, aturan, dan institusi yang mempengaruhi pengarahan, pengelolaan, serta pengontrolan suatu perusahaan atau korporasi. Penerapan corporate governance yang baik berdampak pada laporan keuangan yang dihasilkan, perusahaan atau manajemen akan sulit untuk melakukan manipulasi akuntansi karena terdapat pengawasan dari dewan komisaris sehingga laporan keuangan yang dihasilkan sesuai dengan keadaaan yang sebenarnya dan berintegritas (Nuryanah, 2005).

\section{Ukuran Perusahaan}

Selain keberadaan corporate governance dalam perusahaan, ukuran perusahaan juga dapat mempengaruhi integritas informasi laporan keuangan. Ukuran perusahaan merupakan rata-rata total penjualan bersih untuk tahun yang bersangkutan sampai beberapa tahun berikutya, Brigham dan Houston (2001). Perusahaan dengan ukuran besar diasumsikan dengan jumlah aktiva dan tingkat 
pendapatan yang besar sehingga menghasilkan laba yang tinggi. Sebaliknya jika penjualan lebih kecil daripada biaya variabel dan biaya tetap maka perusahaan akan menderita kerugian. Francis (1986), menyebutkan perusahaan berskala kecil dibandingkan dengan perusahaan yang berskala besar cenderung kurang menguntungkan. Faktor-faktor pendukung yang dimiliki perusahaan kecil untuk memproduksi barang berjumlah terbatas. Namun pada kenyataannya, perusahaan berukuran kecil lebih mampu bertahan menghadapi krisis ekonomi

\section{Leverage}

Teori keagenan memprediksi bahwa perusahaan dengan rasio leverage yang lebih tinggi akan mengungkapkan lebih banyak informasi, karena biaya keagenan perusahaan dengan struktur modal seperti itu lebih tinggi (Jensen dan Meckling, 1976). Tambahan informasi diperlukan untuk menghilangkan keraguan pemegang obligasi terhadap informasi dipenuhinya hak-hak mereka sebagai kreditur (Schipper, 1981) dalam (Marwata, 2001) dan (Meek, 1995) dalam (Fitriany, 2001).

\section{Profitabilitas}

Profitabilitas menunjukkan kemampuan perusahaan untuk menghasillkan laba selama periode tertentu. Rasio profitabilitas merupakan perbandingan antara laba bersih perusahaan terhadap investasi atau ekuitas yang digunakan untuk memperoleh laba perusahaan tersebut. Profitabilitas memberikan informasi yang penting bagi pihak di luar perusahaan untuk melihat efisiensi perusahaan yang dilakukan oleh manajemen.

Menurut Munawir (2007: 33)" Profitabilitas atau rentabilitas adalah kemampuan perusahaan menghasilkan laba selama periode tertentu". Agus Sartono (2001:22) mengatakan "Profitabilitas adalah kemampuan perusahaan memperoleh laba dalam hubungannya dengan penjualan, total aktiva maupun modal sendiri." Sedangkan Brigham dan Houston (2006: 107), Profitabilitas adalah hasil akhir dari sejumlah kebijakan dan keputusan yang dilakukan perusahaan. Rasio profitabilitas akan menunjukkan kombinasi efek-efek dari likuiditas, manajemen aktiva, dan utang pada hasil-hasil operasi.

\section{Penelitian Terdahulu}

Berbagai penelitian mengenai pengungkapan laporan tahunan telah dilakukan. Namun, masih sedikit penelitian yang meneliti tentang pengungkapan corporate governance. Hal ini mungkin disebabkan karena isu mengenai corporate governance baru muncul setelah krisis ekonomi yang terjadi pada tahun1997. 
Yasmeen dan Hernawati (2015) meneliti tentang pengaruh Good Corporate Governance terhadap kualitas pelaporan keuangan pada perusahaan Manufaktur. Berdasarkan hasil pengujian hipotesis dapat disimpulkan bahwa Leverage berpengaruh terhadap Kualitas Pelaporan Keuangan ; sedangkan Dewan Komisaris, Kepemilikan Institusional, Kepemilikan Manajerial dan umur perusahaan (Age) tidak berpengaruh terhadap kualitas pelaporan keuangan.

\section{Kerangka Konseptual}

Dalam penelitian ini yang ingin diteliti adalah pengaruh corporate governance yang diproksikan dengan kepemilikan institusional, kemudianleveragedan ukuran perusahaan sebagai variabel independen serta profitabilitas sebagai variabel moderating terhadapkualitas laporan keuangan sebagai variabel dependen.

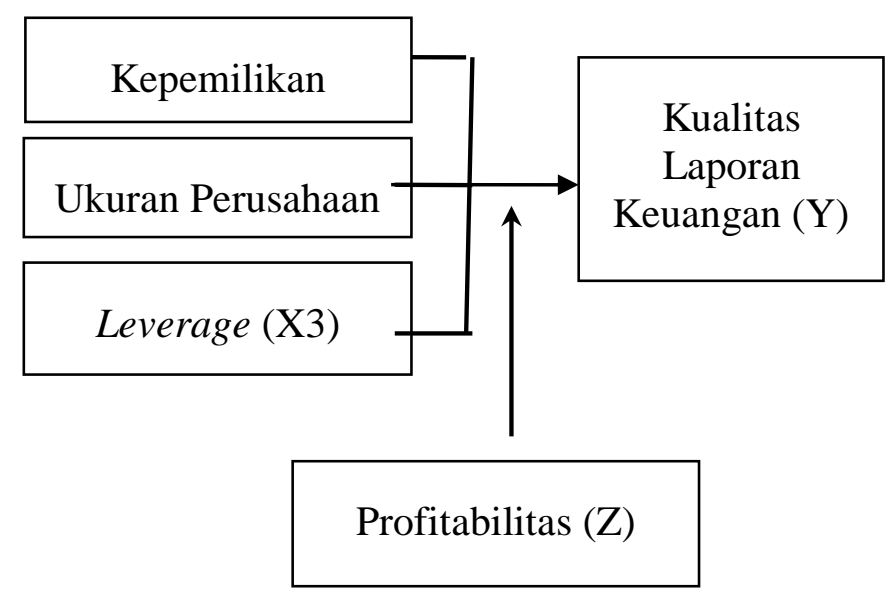

Gambar 3.1

Kerangka Konseptual

\section{Hipotesis}

Berdasarkan latar belakang teoritis yang sudah dijelaskan diatas, hipotesis dari penelitian ini dapat diuraikan sebagai berikut:

1. Coporate Governance, Ukuran Perusahaan, Leverage dan Profitabilitas secara parsial dan simultan berpengaruh signifikan terhadap kualitas laporan keuangan.

2. Profitabilitas memoderasi hubungan Coporate Governance, Ukuran Perusahaan, Leverageterhadap kualitas laporan keuangan. 


\section{METODE PENELITIAN}

\section{Jenis Penelitian}

Jenis penelitian yang dilakukan adalah penelitian asosiatif kausal. Menurut Umar (2003 : 30) penelitian asosiatif kausal adalah penelitian yang bertujuan untuk menganalisis hubungan antara satu variabel dengan variable lainya atau bagaimana suatu variabel mempengaruhi variabel lain. Variabel Independen (X) dalam penelitian ini adalah corporate governance yang diukur menggunakan kepemilikan institusional, ukuran perusahaan yang diukur menggunakan lagaritma natural total aset, leverage yang diukur menggunakan Debt to Assets Ratio, variabel moderatingnya adalah profitabilitas yang diukur menggunakan Return On Assetsdan untuk kemudian diuji dan dianalisis pengaruhnya terhadap kualitas laporan keuangan (Y) sebagai variabel dependen dalam penelitian ini.

\subsection{Tempat dan Waktu Penelitian}

Penelitian ini dilakukan pada perusahaan-perusahaan manufaktur yang listing di Bursa Efek Indonesia (BEI) melalui media perantara dengan melakukan browsing pada situs web http://www.bei.co.id. Waktu penelitian dilakukan 2018

\subsection{Populasi dan Sampel}

Populasi adalah keseluruhan subjek penelitian,bila ingin meneliti semua elemen yang ada maka sesebut studi populasi atau sensus Arikunto (2006). Populasi adalah sekelompok orang,kejadian, suatu yang mempunyai karakteristik tertentu. Populasi yang akan digunakan dalam penelitian ini adalah semua perusahaan manufaktur yang terdaftar di BEIpada tahun 2010-2014 yang berjumlah 132 perusahaan.

Sampel adalah bagian populasi yang digunakan untuk memperkiral 33 karakteristik populasi. Oleh sebab itu, sampel yang diambil dari populasi ha benar-benar representatif atau mewakili. (Jogiyanto 2004)Pengembalian sampel bertujuan (purposive sampling) dilakukan dengan mengambil sampel dari populasi berdasarkan suatu kriteria tertentu.Adapun sampel yang dipilih dalam penelitian ini adalah perusahaan yang memenuhi kriteria sebagai berikut :

1. Perusahaan manufaktur menerbitkan laporan keuangan yang telah diaudit periode $2014-2018$.

2. Perusahaan memiliki laba positif selama 5 tahun berturut-turut.

Penentuan populasi dan sampel penelitian dapat dilihat pada lampiran. Berikut ini adalah ringkasan hasil penarikan sampel sesuai kriteria.

Tabel 4.1

\section{Penentuan Populasi danSampel Penelitian}

Keterangan Krit




\begin{tabular}{|c|c|}
\hline & eria \\
\hline $\begin{array}{l}\text { Merupakan perusahaan industri } \\
\text { manufaktur dan menyajikan laporan } \\
\text { keuangan secara lengkap yang telah } \\
\text { diaudit oleh Akuntan Publik sepanjang } \\
\text { tahun } 2014-2018 \text {. } \\
\text { Perusahaan tidak memiliki laba positif } \\
\text { berturut-turut selama tahun } 2014 \text { - } 2018 \text {. }\end{array}$ & $\begin{array}{c}(67 \\
)\end{array}$ \\
\hline Sampel yang digunakan & 65 \\
\hline
\end{tabular}

Berdasarkan penarikan sampel maka dioperoleh 65 perusahaan dengan menggunakan pooling data yaitu penggabungan data timeseries dan cross sectional sehingga diperoleh data sebanyak 325 diperoleh dari 65 perusahaan selama 5 tahun. Daftar penarikan sampel terlihat pada lampiran. Berikut ini adalah nama-nama perusahaan yang terpilih dijadikan sampel penelitian.

Tabel 4.2. Daftar Nama SampelPerusahaan

\begin{tabular}{|c|l|l|}
\hline No & Kode & Nama Perusahaan \\
\hline 1 & ALKA & Alakasa Industrindo Tbk \\
\hline 2 & AMFG & Asahimas Flat Glass Tbk \\
\hline 3 & ARNA & Arwana Citramulia Tbk \\
\hline 4 & ASII & Astra Internasional Tbk \\
\hline 5 & AUTO & Astra Otoparts Tbk \\
\hline 6 & BATA & Sepatu Bata Tbk \\
\hline 7 & BRAM & Indo Kordsa Tbk \\
\hline 8 & BRNA & Berlina Tbk \\
\hline 9 & BTON & Betonjaya Manunggal Tbk \\
\hline 10 & CEKA & Wilmar Cahaya Indonesia Tbk \\
\hline 11 & CPIN & Chareon Pokphand Indonesia \\
\hline 12 & CTBN & Citra Tubindo Tbk \\
\hline 13 & DLTA & Delta Djakarta Tbk \\
\hline 14 & DVLA & Darya-Varia Laboratoria Tbk \\
\hline 15 & EKAD & Ekadharma International Tbk \\
\hline 16 & FAST & Fast Food Indonesia Tbk \\
\hline 17 & GDST & Gunawan Dianjaya Steel Tbk \\
\hline 18 & GDYR & Goodyear Indonesia Tbk \\
\hline 19 & GGRM & Gudang Garam Tbk \\
\hline 20 & GJTL & Gajah Tunggal Tbk \\
\hline 21 & HMSP & HM Sampoerna Tbk \\
\hline
\end{tabular}




\begin{tabular}{|c|c|c|}
\hline 22 & ICBP & $\begin{array}{l}\text { Indofood CBP Sukses Makmur } \\
\text { Tbk }\end{array}$ \\
\hline 23 & IGAR & $\begin{array}{l}\text { Champion Pacific Indonesia } \\
\text { Tbk }\end{array}$ \\
\hline 24 & IKBI & Sumi Indo Kabel Tbk \\
\hline 25 & IMAS & $\begin{array}{l}\text { Indomobil Sukses } \\
\text { Internasional Tbk }\end{array}$ \\
\hline 26 & INAI & Indal Aluminium Industry Tbk \\
\hline 27 & INDF & $\begin{array}{l}\text { Indofood CBP Sukses Makmur } \\
\text { Tbk }\end{array}$ \\
\hline 28 & INDR & Indo-Rama Synthetics Tbk \\
\hline 29 & INDS & Indospring Tbk \\
\hline 30 & INTP & $\begin{array}{l}\text { Indocement Tunggal Perkasa } \\
\text { Tbk }\end{array}$ \\
\hline 31 & IPOL & $\begin{array}{l}\text { Indopoly Swakarsa Industry } \\
\text { Tbk }\end{array}$ \\
\hline 32 & KBLI & KMI Wire and Cable Tbk \\
\hline 33 & KBLM & Kabelindo Murni Tbk \\
\hline 34 & KDSI & Kedawung Setia Industrial Tbk \\
\hline 35 & KICI & Kedaung Indah Can Tbk \\
\hline 36 & KLBF & Kalbefarma Tbk \\
\hline 37 & LION & Lion Metal Works Tbk \\
\hline 38 & LMSH & Lionmesh Prima Tbk \\
\hline 39 & MASA & Multistrada Arah Sarana Tbk \\
\hline 40 & MERK & Merck Tbk \\
\hline 41 & MYOR & Mayora Indah Tbk \\
\hline 42 & MYRX & Hanson International Tbk \\
\hline 43 & NIPS & Nipress Tbk \\
\hline 44 & PBRX & Pan Brothers Tbk \\
\hline 45 & $\mathrm{PICO}$ & Pelangi Indah Canindo Tbk \\
\hline 46 & PRAS & $\begin{array}{l}\text { Prima Alloy Steel Universal } \\
\text { Tbk }\end{array}$ \\
\hline 47 & PSDN & Prasidha Aneka Niaga Tbk \\
\hline 48 & ROTI & Nippon Indosari Corpindo Tbk \\
\hline 49 & $\mathrm{SCCO}$ & $\begin{array}{l}\text { Supreme Cable Manufacturing } \\
\& \text { Commerce Tbk }\end{array}$ \\
\hline 50 & SIPD & Sierad Produce Tbk \\
\hline 51 & SKLT & Sekar Laut Tbk \\
\hline 52 & SMCB & Holcim Indonesia Tbk \\
\hline 53 & SMGR & Semen Indonesia (Persero) Tbk \\
\hline 54 & SMSM & Selamat Sempurna Tbk \\
\hline 55 & SRSN & Indo Acidatama Tbk \\
\hline 56 & STTP & Siantar Top Tbk \\
\hline 57 & TCID & Mandom Indonesia Tbk \\
\hline
\end{tabular}




\begin{tabular}{|c|l|l|}
58 & TKIM & Pabrik Kertas Tjiwi Kimia Tbk \\
\hline 59 & TOTO & Surya Toto Indonesia Tbk \\
\hline 60 & TRST & Trias Sentosa Tbk \\
\hline 61 & ULTJ & $\begin{array}{l}\text { Ultrajaya Milk Industry \& } \\
\text { Trading Co. Tbk }\end{array}$ \\
\hline 62 & UNIC & Unggul Indah Cahaya Tbk \\
\hline 63 & UNIT & Nusantara Inti Corpora Tbk \\
\hline 64 & UNVR & Unilever Indonesia Tbk \\
\hline 65 & VOKS & Voksel Electric Tbk \\
\hline
\end{tabular}

\section{Jenis Data dan Metode Pengumpulan Data}

Jenis data penelitian ini adalah data dokumenter yang diperoleh peneliti secara tidak lansung melalui media perantara (diperoleh dan dicatat oleh pihak lain).Sumber data yang digunakan untuk penelitian ini adalah data sekunder yang diperoleh melalui Indonesian Capital Market Directory, Situs resmi BEI, dan observasi ke PT IDX Medan.Penelitian menggunakan data dari laporan keuangan perusahaan-perusahaan sampel. Populasi dalam penelitian ini adalah perusahaan manufaktur yang memiliki laba positif periode 2014-2018 yang berjumlah 65 perusahaan. Daftar populasi perusahaan tercantum dalam lampiran 1.

Prosedur ini ditempuh untuk mencari data melalui dokumentasi dari berbagai media seperti internet dan publikasi. Objek penelitian ini adalah kualitas laporan keuangan pada seluruh perusahaan manufaktur go public yang listing tahun 2014-2018.

\section{Definisi Operasional dan Metode Pengukuran Variabel Variabel Tidak Bebas (Dependen)}

Variabel tidak bebas dalam penelitian ini adalah kualitas laporan keuangan (Y). Variabel kualitas laporan keuangan diproksikan dengan kualitas akrual. Untuk bisa mengukur nilai dari akrual tersebut, maka penelitian ini akan mengikuti model pengukuran akrual yang terbaru yang dilakukan oleh Kothari et al. (2005). Berikut adalah model perhitungan akrual yang dilakukan Kothari et al. (2005).

$T A i, t=\alpha 0+\alpha 1[$ ASSETSi] $+\alpha 24 S A L E S i, t+\alpha 3 R O A i, t$

Keterangan :

$T A i, t=$ ukuran mengenai total akrual ukuran perusahaan i pada tahun $\mathrm{t}$ $\triangle S A L E S i, t=$ perubahan besarnya penjualan perusahaan $\mathrm{i}$ pada tahun $\mathrm{t}$ ROAi, or $i, t-1=$ pengukuran kinerja yang berasal dari tingkat pengembalian aset. ASSETSi, $t-1=$ jumlah nilai total aset perusahaan pada periode sebelumnya

Nilai residual yang diperoleh inilah yang akan digunakan sebagai ukuran dari kualitas laporan keuangan (Dechow and Dichev, 2002). Nilai residual 
tersebut kemudian diabsolutkan, kemudian nilai absolut discretionary accrual ini akan digunakan sebagai pengukuran kualitas laporan keuangan

\section{HASIL DAN PEMBAHASAN}

Berdasarkan hasil uji statistik $\mathrm{F}$ yang dilakukan, diketahui Variabel independen yaitu kepemilikan institusional (KI), ukuran perusahaan (SIZE), leverage (DAR) dan profitabilitas (ROA) secara simultan berpengaruh positif dan signifikan terhadap kualitas laporan keuangan pada perusahaan manufaktur yang terdaftar di BEI tahun 2014-2018. Hasil penelitian ini sejalan dengan hasil riset Rinawati dan Paulus Wardoyo (2010) yang membuktikan faktor-faktor yang mempengaruhi Kualitas Laporan Keuangan secara bersama-sama berpengaruh signifikan. Besarnya kontribusi faktor-faktor yang mempengaruhi Kualitas Laporan Keuangan adalah 44,4\% yang berarti bahwa persentase pengaruh variabel kepemilikan institusional (KI), ukuran perusahaan (SIZE), leverage (DAR) dan profitabilitas (ROA) terhadap Kualitas Laporan Keuangan adalah sebesar nilai koefisien determinasi atau 44,4\%. Sedangkan sisanya 55,6\% dipengaruhi atau dijelaskan oleh Variabel lain yang tidak dimasukkan dalam model penelitian ini.

\section{Pengaruh Kepemilikan Institusional (KI) terhadapKualitas Laporan Keuangan}

Hasil pengujian Variabel kepemilikan institusional (KI) terhadap Kualitas Laporan Keuangan menggunakan uji t, dapat disimpulkan bahwa variabel kepemilikan institusional (KI) tidak berpengaruh signifikan terhadap kualitas laporan keuangan pada perusahaan Manufaktur yang terdaftar di BEI tahun 20142018. Hasil pengujian menolak hipotesis. Hasil ini konsisten dengan hasil penelitian yang dilakukan oleh Yasmeen dan Hernawati (2015) yang membuktikan kepemilikan institusional (KI) tidak berpengaruh terhadap Kualitas Laporan Keuangan.

\section{Pengaruh Ukuran Perusahaan (SIZE) terhadapKualitas Laporan Keuangan}

Hasil pengujian variabel ukuran perusahaan (SIZE) terhadap Kualitas Laporan Keuangan menggunakan uji t, dapat disimpulkan bahwa variabel ukuran perusahaan (SIZE) tidak berpengaruh signifikan terhadap kualitas laporan keuangan pada perusahaan Manufaktur yang terdaftar di BEI tahun 2014-2018. Hasil pengujian menolak hipotesis. Hasil ini belum dapat dikaitkan dengan penelitian terdahulu karena adanya perbedaan dalam menggunakan variabel. Namun hasil penelitian ini secara statistik dapat menjelaskan pengaruh positif dan tidak signifikan ukuran perusahaan (SIZE) terhadap Kualitas Laporan Keuangan. 


\section{Pengaruh Leverage (DAR) terhadap Kualitas Laporan Keuangan}

Hasil pengujian variabel leverage (DAR)terhadap kualitas laporan keuangan menggunakan uji t, dapat disimpulkan bahwa variabel leverage (DAR) berpengaruh positif dan signifikan terhadap kualitas laporan keuangan pada perusahaan manufaktur yang terdaftar di BEI tahun 2014-2018. Hasil ini sejalan dengan hasil penelitian yang dilakukan Yasmeen dan Hernawati (2015) membuktikan Leverage (DAR) berpengaruh signifikan terhadap Kualitas Laporan Keuangan.

\section{Pengaruh Profitabilitas (ROA) terhadap Kualitas Laporan Keuangan}

Hasil pengujian variabel profitabilitas (ROA) terhadap kualitas laporan keuangan menggunakan uji $\mathrm{t}$, dapat disimpulkan bahwa variabel profitabilitas (ROA) berpengaruh signifikan terhadap kualitas laporan keuangan pada perusahaan manufaktur yang terdaftar di BEI tahun 2014- 2018. Hasil ini mendukung hasil penelitian yang dilakukan oleh Fanani (2008) yang membuktikan profitabilitas berpengaruh terhadap Kualitas Laporan Keuangan.

\section{Pengaruh Variabel Moderating (profitabilitas)}

Setelah pengujian hipotesis kedua dilakukan, maka dilakukan pengujian kembali menggunakan Variabel moderating yakni profitabilitas yang diukur menggunakan ROA. Pengujian hipotesis kedua ini menggunakan uji selisih mutlak (metode residual), disimpulkan bahwa variabel profitabilitas memiliki pengaruh positif dan signifikan terhadap nilai absolute residual. Sehingga, dapat disimpulkan bahwa Variabel profitabilitas merupakan variabel moderating yang memperkuat atau memperlemah hubungan antara kepemilikan institusional (KI), ukuran perusahaan (SIZE) dan leverage (DAR) terhadap kualitas laporan keuangan perusahaan Manufaktur di BEI.

\section{KESIMPULAN DAN SARAN}

1. Variabel kepemilikan institusional (KI), ukuran perusahaan (SIZE), leverage (DAR) dan profitabilitas (ROA) secara simultan berpengaruh signifikan terhadap Kualitas Laporan Keuangan. Secara parsial terbukti variabel kepemilikan institusional (KI) dan ukuran perusahaan (SIZE) tidak berpengaruh signifikan terhadap Kualitas Laporan Keuangan pada perusahaan manufaktur terdaftar di Bursa Efek Indonesia untuk periode. Pengujian secara parsial variabel leverage (DAR) dan profitabilitas (ROA) berpengaruh signifikan terhadap Kualitas Laporan Keuangan pada perusahaan manufaktur terdaftar di Bursa Efek Indonesia untuk periode 2014-2018. 
2. Variabel profitabilitas dapat dikatakan sebagai variabel moderating yang dapat memperkuat atau memperlemah kepemilikan institusional (KI), ukuran perusahaan (SIZE) dan leverage (DAR) terhadap Kualitas Laporan Keuangan pada perusahaan manufaktur yang terdaftar di BEI untuk periode 2014-2018.

\section{Keterbatasan}

Keterbatasan nilai R-Square yang rendah menunjukkan dalam menggunakan faktor-faktor yang mempengaruhi Kualitas Laporan Keuangan masih kecil dengan kemungkinan masih terdapat banyak lagi faktor-faktor yang berpengaruh terhadap Kualitas Laporan Keuangan seperti manajemen laba, kebijakan deviden, likuiditas, free cash flow..

1. Keterbatasan menggunakan sampel yaitu hanya pada perusahaan manufaktur yang memperoleh laba positif saja sehingga belum dapat dijadikan dasar keputusan secara umum terhadap perusahaan-perusahaan yang terdaftar di BEI.

\section{Saran}

1. Peneliti selanjutnya diharapkan menambah jumlah Variabel independen lainnya misalnya manajemen laba, kebijakan deviden, likuiditas, free cash flow dan faktor lainnya sehingga dengan menambah Variabel akan menambah temuan baru yang lebih baik lagi yang diduga dapat mempengaruhi Kualitas Laporan Keuangan.

2. Peneliti selanjutnya diharapkan menambah sampel selain perusi manufaktur seperti sektor perbankan, sektor telekomunikasi, sektor perdagangan dan sektor lainnya agar hasil penelitiannya lebih baik lagi

\section{DAFTAR PUSTAKA}

Ashbough, H., Collins, D., and Laford, R., 2004. Corporate Governance the Costof Equity Capital, Working Paper, University of Lowa.

Diitmar. et. al. International Corporate Governance and Corporate Case Holdings. Journal of Financial and Quantitative Analysis Vol 38 no.1 March 2003. School of Business Administration. University of Washington, Seattle WA 98195. 
Diah Kusuma Wardhani. (2008). "Pengaruh Cor-porate Governance Terhadap Kinerja Pe-rusahaan di Indonesia”. Skripsi. Universitas Islam Indonesia

Foster. 1986. Financial Statement Analysis. USA: Prentice Hall International.

Henetigala. 2011. Corporate Governance Practices and Firm Performance of Listed Companies in Sri Lanka. Melbourne: Victoria Graduate School

Jama'an, Jan. 2008. Pengaruh Mekanisme Corporate Governance dan Kualitas Kantor Akuntan Publik terhadap Integritas Informasi Laporan Keuangan. Semarang: Universitas Diponegoro.

Jensen, Michael C. dan W.H. Meckling. 1976. Theory of The Firm: Managerial Behavior, Agency Cost and Ownership Structure. Journal of Financial Economics. Vol. 3: Hal. 305-360.

Kasmir. 2011. Analisis Laporan Keuangan, Edisi 4, Jakarta: PT Raja Grafindo Persada.

Kusumawati, Dwi Novi 2007. "Profitability and Corporate Governance Disclosure: An Indonesian Study", Jurnal Riset Akuntansi Indonesia, Vol. 10, No. 2, Hal. 131-146.

Lako, Andreas. 2007. Laporan Keuangan dan Konflik Kepentingan, Edisi Kedua, Yogyakarta: Amara Books.

Manawaduge. 2012. Corporate Governance Practices and Their Impacts on Corporate Perfomance in Emerging Market. Doctor of Philosopy Thesis, School of Accounting and Finance University. Research Online 2012: http: / / row.now.edu.au/theses/3676

Marwata. 2001. "Hubungan Antara ${ }^{46}$ steristik Perusahaan dan Kualitas Ungkapan Sukarela dalam Lapuian Tahunan Perusahaan Publik di Indonesia”, Simposium Nasional Akuntansi IV, Hal. 155-173.

Na'im, Ainun dan Fu'ad Rakhman. 2000. “Analisis Hubungan Antara Kelengkapan Pengungkapan Laporan Keuangan dengan Struktur Modal dan Tipe Kepemilikan Perusahaan", Jurnal Ekonomi dan Bisinis Indonesia, Vol. 15, No. 1, Hal. 70-82

Ndoen. 2011. Pengaruh Penerapan Corporate Governance Terhadap Penerimaan Opini Audit Going Concern. Yogyakarta: Universitas Atmajaya. 
Nur Sayidah dan Diyah Pujiati. (2008). "Corporate Governance dan Rasio Utang Perusahaan”. Jurnal Ventura Vol. 11, No. 3, Desember 2008.

Nuryanah, Siti. 2005. Corporate Governance Practice in Indonesia, Status Quo An Empirical Study of the Relationship between Corporate Governance Practice and Performance of Listed Companies.

Retno, 2012. Pengaruh Good Corporate Governance dan Pengungkapan Corporate Social Responsibility Terhadap Nilai Perusahaan (Studi Empiris yang Terdaftar di Bursa Efek Indonesia Periode 2007-2010). Jurnal Nominal/Volume 1 Nomor 1/ Tahun 2012

Santoso, Singgih. 2004. SPSS Versi 10: Mengolah Data Statistik Secara Profesional. Cetakan 5. Jakarta: PT Elex Media Komputindo.

Simanjuntak, B. H. dan Lusy Widiastuti. 2004. "Faktor-Faktor yang Mempengaruhi Kelengkapan Pengungkapan Laporan Keuangan pada Perusahaan Manufaktur yang Terdapat di Bursa Efek Jakarta", Jurnal Riset Akuntansi Indonesia, Vol. 7, No. 3, Hal. 351-366.

Wibowo, J. 2002. Implikasi Konservatisme dalam Hubungan Laba-Return dan Faktor-Faktor yang Mempenagruhinya, Tesis tidak diterbitkan. Jogjakarta: Fakultas Ekonomi, UGM.

Widya. 2005. Analisis Faktor-Faktor yang mempengaruhi Pilihan Perusahaan Terhadap Akuntansi Konservatif, Jurnal Riset Akuntansi Indonesia, Volume 8, No.2: Hal 138-157.

Ikatan Akuntansi Indonesia. 2004. Standar Akuntansi Keuangan. Salemba Empat. Jakarta.

Komite Nasional Kebijakan Governance. 2006. Pedoman Umum Good Corporate Governance Indonesia, Jakarta

OECD (Organisation for Economic Co-operation and Development). 1999. OECD Principles of Corporate Governance. OECD Publications Service. France: $9-19$

OECD. 1999. Corporate Governance Improving Competitiveness and Access to Global Capital Market. Corporate Governance: An International Review, vol. 7, pp. 198-206 